\title{
Spectrum of male breast lesions: an institutional perspective
}

\author{
Ganguly $\mathbf{S}^{1}$, Sheikh $\mathrm{SA}^{2}$, Phukan $\mathrm{A}^{3}$, Das $\mathbf{J}^{4}$, Das S.S \\ ${ }^{1}$ Dr Siyum Ganguly, Demonstrator, ${ }^{2}$ Dr Shah Alam Sheikh, Associate Professor, ${ }^{3}$ Dr Angela Phukan, Postgraduate \\ student, ${ }^{4}$ Dr Jahnabi Das, Postgraduate student, Dr Surjya Sekhar Das, Postgraduate student, All are affiliate with \\ Department of Pathology, Silchar Medical College and Hospital, Silchar, Assam, India
}

Address for correspondence: Dr Shah Alam Sheikh, Email: shahalamsheikh61@gmail.com

\begin{abstract}
Background: Fine needle aspiration is a quick and effective method in the diagnosis of breast lumps and is being widely used in the preoperative assessment of breast lesions. Studies related to male breast lesions are rare. The aim of our study is to study the spectrum of male breast lesions and to analyze the cytological spectrums of these lesions. Materials and Methods: The study was conducted over a period of 5 years. FNAC was done on all male patients clinically presenting with breast lesions. Cytological findings were retrospectively correlated with histopathological dignosis. FNAC diagnosis was categorized as benign, malignant, suspicious of malignancy and unsatisfactory. Results: Male breast lesions formed $6.2 \%$ (38 cases) of the 612 breast lesions which were sent for FNA over a period of 5 years. Of these histopathological examination was done only in 19 cases. $86.8 \%$ (33 cases) were benign or reactive and 10.6\% (4 cases) were malignant. Gynecomastia was the commonest benign lesion (29 cases). Conclusion: This study showed that FNAC is a reliable, sensitive and specific diagnostic tool for diagnosing male breast lesions. Hence, it should be used as a first line of investigation in the evaluation of male breast lesions.
\end{abstract}

Keywords: FNAC, Gynecomastia, Infiltrating duct carcinoma, Male breast lesions

\section{Introduction}

Fine needle aspiration cytology is a quick, accurate and cost effective method in the diagnosis and management of various lesions. Fine-needle aspiration of the breast is being used increasingly in the preoperative assessment of breast lesions. Most studies, however, were dominated by the large number of female breast lesions, with the male breast lesions representing less than $1 \%$ of the studied cases[1-2]. Gynecomastia is the most common cause of benign masses in the male breast. Male breast cancer is extraordinarily rare, and as it is associated with an aggressive clinical course [3]. Although histologic examination is a sure means of distinguishing gynecomastia from carcinoma, it is both impractical and unnecessary to perform a biopsy on all patients with gynecomastia [4]. Studies show that use of fine needle aspiration (FNA) can allow diagnosis to be made with a sufficient degree of confidence which can spare the patient an invasive surgical procedure [5].

Manuscript received: $16^{\text {th }} \mathrm{Feb} 2016$

Reviewed: $25^{\text {th }}$ Feb 2016

Author Corrected: 04 $4^{\text {th }}$ March 2016

Accepted for Publication: $13^{\text {rd }}$ March 2016

\section{Aims and objectives}

The aims and objectives of this study are to study the spectrum of male breast lesions and to analyze the cytological spectrum of these lesions.

\section{Material and Methods}

Study design: This research included all male patients clinically presenting with breast lesions referred to the Department of Pathology, Silchar Medical College and Hospital for FNAC and histopathological evaluation and a retrospective study was conducted from June 2010 to July 2015.

Data collection and analysis: All aspirates were performed using 23-25 gauge needle and five $\mathrm{ml}$ syringe. Air dried smears were prepared and stained by the May-Grunwald-Giemsa method. In addition, smears were wet-fixed in $95 \%$ ethyl alcohol and subsequently stained with Papanicolaou stain. The smears were classified into five major diagnostic categories:

i) Unsatisfactory

ii) Benign

iii) Atypical suggestive of benign 
iv) Suspicious of malignancy

v) Malignant
Histopathological diagnosis was obtained and the cytological diagnosis was retrospectively correlated with histological findings.

\section{Results}

Over a 5 year period, 612 patients with palpable breast lumps underwent Fine needle aspiration (FNAC) at our hospital. Of these, 38 were males and out of which 36 had unilateral breast lumps, and 2 patients had bilateral breast lumps. Out of the patients having unilateral breast lumps, 22 patients had left breast lump and 14 had right breast lump. The age of the patients ranged from 12 years to 85 years with a mean age of 40.1years. A repeat aspirate was performed in 4 cases with an initial unsatisfactory aspirate; and in 3 cases the repeat aspirate yielded adequate material. Overall, unsatisfactory aspirates were obtained in $2.6 \%$ of cases ( 1 Case). The aspirates were each categorized into the following groups: benign/ reactive $33(86.8 \%)$, malignant $2(5.3 \%)$, atypical/suspicious for malignancy $2(5.3 \%)$ and nondiagnostic/unsatisfactory $1(2.6 \%)$. Histopathological diagnosis was available in 19 cases. The most common diagnostic entity encountered in our study was gynecomastia (30 cases). Smears showed variable cellularity, ranging from scanty to markedly cellular smears. Smears showed large, tightly cohesive epithelial fragments often appearing as flat monolayered sheets. Often there is a bimodal pattern of stroma and epithelial cells in addition to single bare bipolar/oval nuclei in the background. Only thirteen cases were confirmed histologically and one case was found to be fibroadenoma. We had two cases of duct carcinoma characterized by hypercellular smears, irregular cell clusters as well as single cells and absence of myoepithelial cells. These cells had moderate to severe nuclear pleomorphism, irregular nuclear membrane and chromatin, prominent nucleoli and abundant eosinophilic cytoplasm. Histologically they were diagnosed as infiltrating duct carcinoma (NOS). Two cases of infiltrating duct carcinoma were diagnosed cytologically as suspicious of malignancy, later confirmed on histopathological examination. We had one case of lipoma, presenting as well defined rounded soft mass and characterized by presence of fat vacuoles and fragments of adipose tissue. Diffuse sheets of inflammatory cells, predominantly composed of neutrophils admixed with lymphocytes and histiocytes were seen amidst occasional sheets of ductal epithelial cells in a case of breast abscess. Plenty of anucleate squamous and mature squamous cells were seen in a case of keratinous cyst.

Table 1: Distribution of cases according to cytological diagnosis

\begin{tabular}{|l|l|}
\hline Cytologic diagnosis & Number of cases \\
\hline Benign neoplasms & 30 \\
Gynecomastia & 1 \\
Lipoma & 1 \\
Keratinous cyst & \\
\hline Malignant neoplasms & 2 \\
Duct carcinoma & 2 \\
Suspicious of malignancy & 1 \\
\hline Inflammatory/abscess & 1 \\
\hline Non diagnostic/ unsatisfactory & \\
\hline
\end{tabular}

Table 2: Cyto-histological correlation of the 19 cases where biopsy was performed:

\begin{tabular}{|l|l|l|}
\hline Cytological diagnosis & Histopathological diagnosis & Number \\
\hline Gynecomastia & $\begin{array}{l}\text { Gynecomastia } \\
\text { Fibroadenoma }\end{array}$ & 12 \\
\hline Duct carcinoma & Duct carcinoma & 2 \\
\hline Suspicious of malignancy & Duct carcinoma & 2 \\
\hline Lipoma & Lipoma & 1 \\
\hline Keratinous cyst & Keratinous cyst & 1 \\
\hline
\end{tabular}




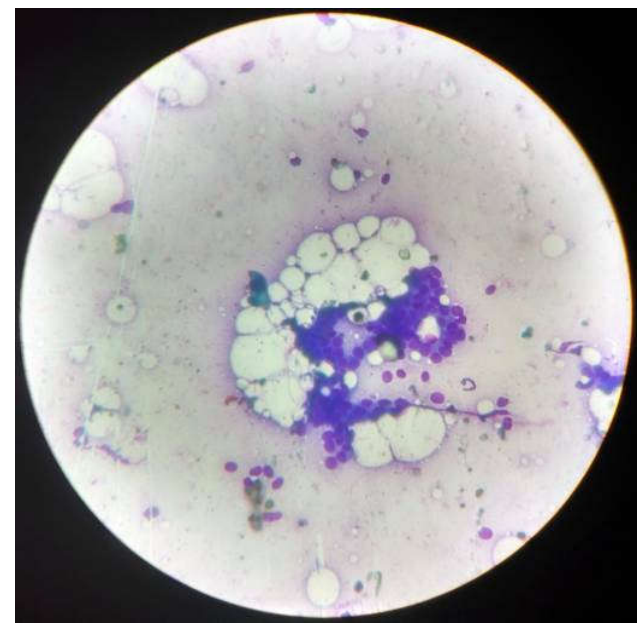

Fig 1: Smear shows cohesive fragments of uniform ductal epithelial cells, suggestive of gynecomastia (MGG, 100X)
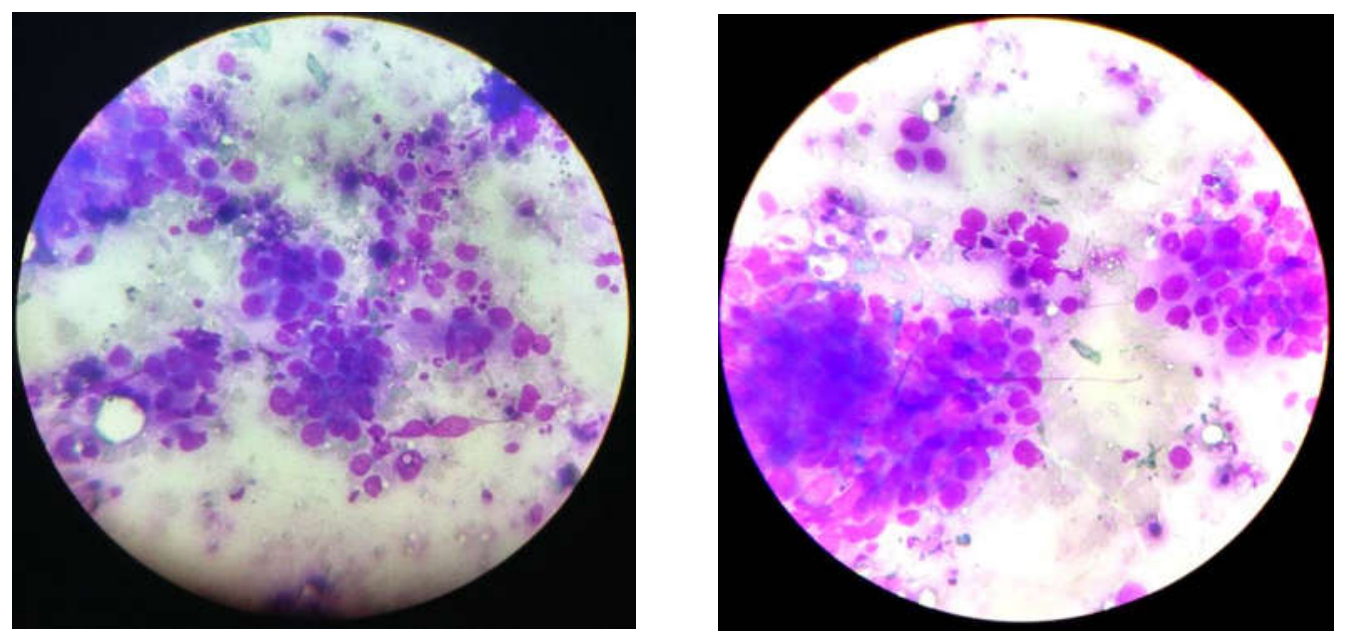

Fig 3a \& b: Smear showing clusters as well as dispersed pleomorphic cells with abundant cytoplasm

and absence of myoepithelial cells, features suggestive of duct carcinoma (Giemsa, 100X)
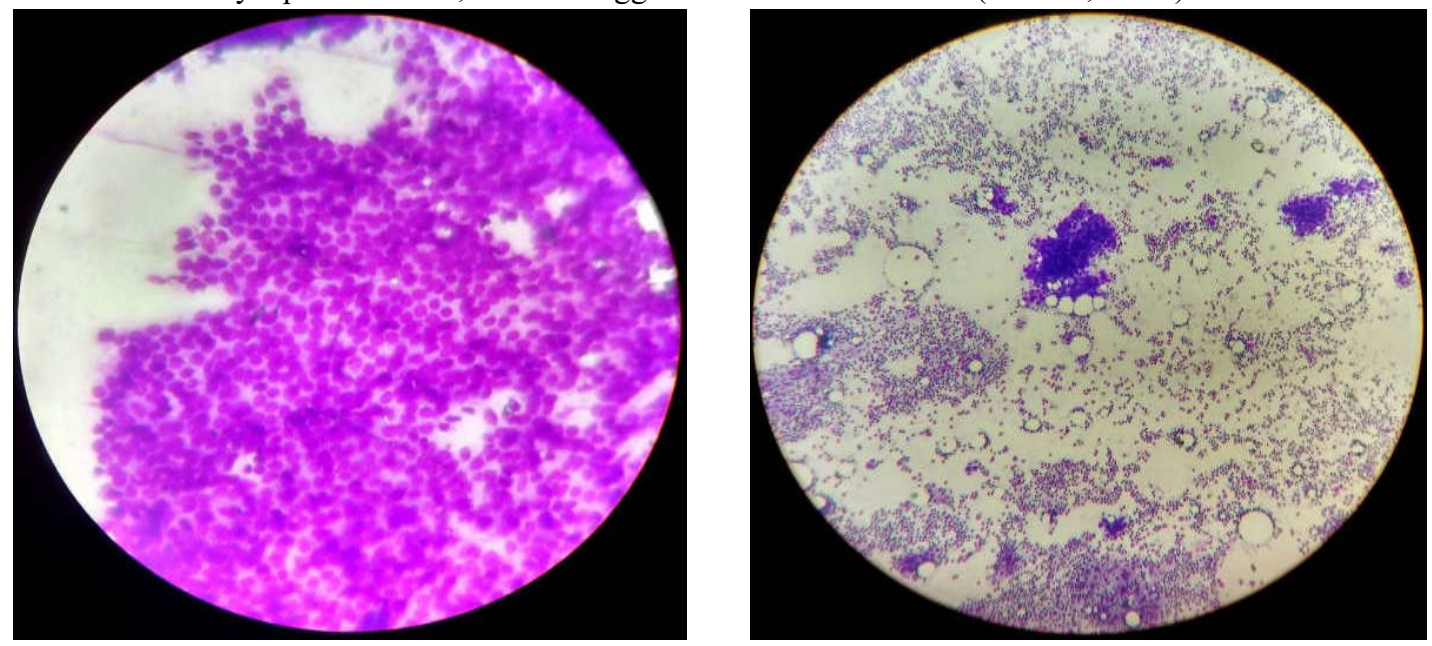

Fig 4a \& b: Smear show features suspicious of malignancy (Giemsa, 100X) 

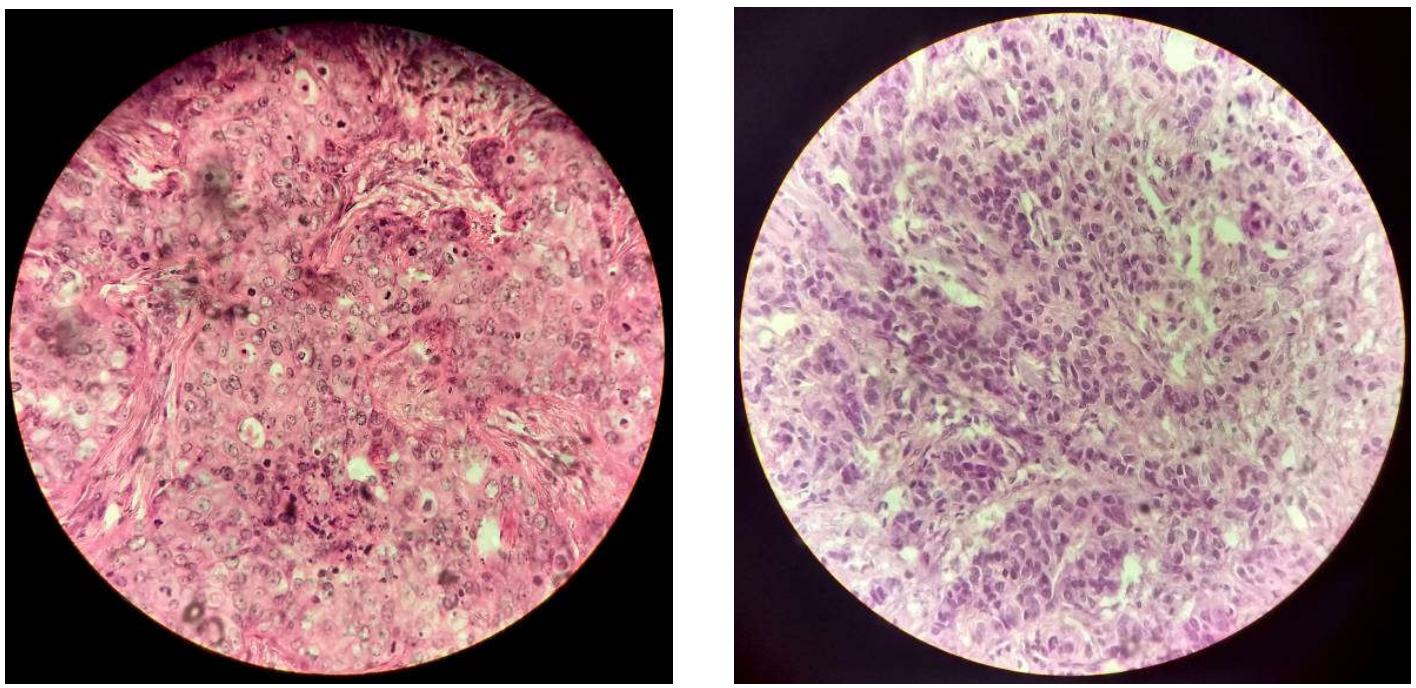

Fig 5a \& b: Section showing features of Infiltrating duct carcinoma (H\&E, 100X)

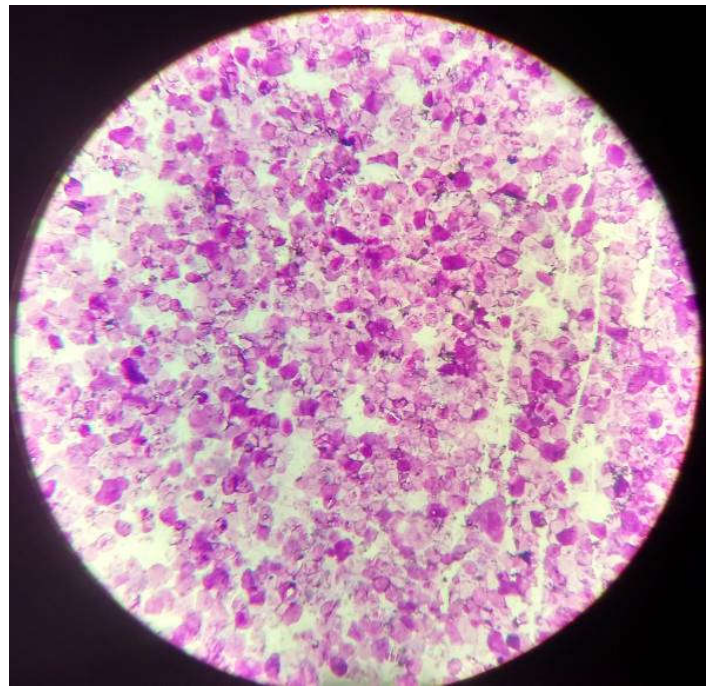

Fig 6: Smear of keratinous cyst showing plenty of anucleate squams and mature squamous cells (Giemsa,100X)

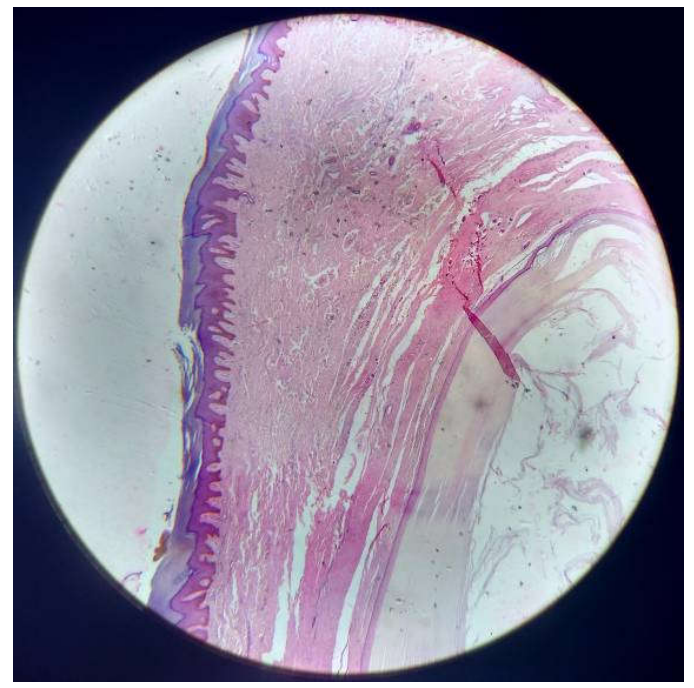

Fig 7: Section showing features of keratinous cyst $(\mathrm{H} \& \mathrm{E}, 100 \mathrm{x})$

\section{Discussion}

Breast masses in males constitute less than $2 \%$ of the total cases in large FNAC studies of breast lumps. Carcinoma in male breast is very rare as compared to the female breast [8-17]. Diagnosis of palpable breast masses by FNAC has gained world-wide acceptance [18]. Most of the studies have however evaluated the usefulness of FNAC in the diagnosis of breast masses in females [18]. The present study was undertaken to analyze the cytological spectrum of male breast lesions. In our series, the total number of patients who underwent FNAC for the assessment of a breast lump was 612 over a 5 year period with males constituting $6.2 \%$ (38 out of 612 ). In our study 29 out of 38 cases (76.3\%) were gynecomastia and $51.7 \%$ (15) of them presented as subareolar mass. Gynecomastia was bilateral in $6.9 \%(2)$ cases and more frequent in the left than right side (17 cases were left sided). This was similar to the studies conducted by Das et al [5] and Martin-Bates et al [19] who observed it more in the left breast. 
The age at presentation was variable with a peak age in the fourth decade. Russin et al [20] observed bimodal peak in the third and seventh decades. Gynecomastia results from different factors that induce a benign proliferation of the duct epithelium and increased periductal deposition of collagen. [21] These different causes share a background of relative increase in estrogenic activity and decrease in androgenic activity or both. [22] A study by Ersek et al showed that in $33 \%$ of pubertal cases, the condition subsided on its own within 1 year, and in $93 \%$ of cases, the condition subsided in 3 years. [23] As our findings show, fine needle aspirates of gynecomastia can have variable cellularity ranging from virtually acellular to richly cellular smears [5].

The male breast carcinomas were easily distinguished on cytology from gynecomastia on the basis of high cellularity, dyscohesive cell groups with nuclear piling and anisonucleosis [5]. These features were observed in almost all cases of carcinoma of male breast. Absence of bipolar bare nuclei was an important clue and only two cases of carcinoma showed benign cells accompanying malignant cells. In the present study, we found that there were two cases of infiltrating duct carcinoma and two cases suspicious of malignancy, which finally turned out to be duct carcinoma on histopathological examination. In our study $10.5 \%$ cases were infiltrating duct carcinoma which is similar to Wauters et al. (10.2\%) [26] and Westend et al. (9.8\%)[25]. Biopsy was available in 50\% cases (19 out of 38) which is similar to that of Wauters et al. (58\%) [26] and Westend et al. (47\%) [25] but in contrast to that of MacIntosh et al. (17\%)[24]. Biopsy rate is less in case of benign lesions.

Table 3: Results of the present study in comparison with other studies

\begin{tabular}{|l|l|l|l|l|}
\hline Result & Westend et al. & MacIntosh et al. & Wauters et al. & Present study \\
\hline Year & 2002 & 2008 & 2009 & 2015 \\
\hline No. of male FNAC & $153(1.5 \%)$ & $138(3.2 \%)$ & $147(1.7 \%)$ & \\
\hline No. of biopsy & $72(47 \%)$ & $23(17 \%)$ & $85(58 \%)$ & $19(50 \%)$ \\
\hline No.of malignant cases & $15(9.8 \%)$ & $11(7.9 \%)$ & $15(10.2 \%)$ & $4(10.5 \%)$ \\
\hline No.of unsatisfactory cases & $18(11.7 \%)$ & $46(33.3 \%)$ & $45(30.6 \%)$ & $1(2.6 \%)$ \\
\hline Sensitivity & $100 \%$ & $95.5 \%$ & $100 \%$ & $100 \%$ \\
\hline Specificity & $89 \%$ & $100 \%$ & $90.2 \%$ & $100 \%$ \\
\hline
\end{tabular}

\section{Conclusion}

FNAC is a reliable, sensitive and specific diagnostic tool for the assessment of breast masses in male patients. The routine use of FNAC would greatly reduce the number of unnecessary biopsies and frozen sections for histopathologic evaluation, especially in case of Gynecomastia. Hence, the use of FNAC as the first-line investigation in the clinical evaluation of male breast lumps is strongly recommended.

Funding: Nil, Conflict of interest: None. Permission of IRB: Yes

\section{References}

1. Gupta RK, Naran S, Dowle CS, Simpson JS. The diagnostic impact of needle aspiration cytology of the breast on clinical decision making with an emphasis on the aspiration cytodiagnosis of male breast masses. Diagn Cytopathol 1991; 7(6):637-9. DOI: $10.1002 /$ dc. 2840070620
2. Eisenberg AJ, Hajdu SI, Wilhelmus J, Melamed MR, Kinne D. Preoperative aspiration cytology of breast tumors. Acta Cytol. 1986 Mar-Apr; 30(2):13546.

3. Siddiqui MT, Zakowski MF, Ashfaq R, Ali SZ: Breast masses in males: multi-instituitional experience on fine needle aspiration. Diag Cytopathology.2002 Feb;26(2): 87-91

4. Nuttal FQ. Gynecomastia as a physical finding in normal men. J Clin Endocrinol Metab 1979 Feb;48(2):338-340. doi: 10.1210/jcem-48-2-338

5. Das DK, Junaid TA, Mathews SB, Ajrawi TG, Ahmed MS, Madda JP. Fine needle aspiration cytology diagnosis of male breast lesions: A study of 185 cases. Acta Cytol 1995 Sep-Oct;39(5):870-876

6. Rosen DG, Laucirica R, Verstovsek G. Fine needle aspiration of male breast lesions. Acta Cytol. 2009 JulAug; 53(4):369-74.

Available online at: $\underline{\text { www.ijmrr.in }} 385$ | P a g e 
7. Silverman JF, Lannin DR, O'Brien K, Norris HT. The triage role of fine needle aspiration biopsy of palpable breast masses- diagnostic accuracy and costeffectiveness. Acta Cytol. 1987 Nov-Dec; 31(6):731-36.

8. Palombini L, Fulciniti F, Vetrani A, et al. Fine needle aspiration biopsies of Breast masses - A critical analysis of 1956 cases in 8 years. Cancer. 1988 Jun 1; 61(11):2273-7.

9. Lilleng R, Paksoy N, Vural G, Langmark F, Hagmar B. Assesment of fine needle aspiration cytology and histopathology for diagnosing male breast masses. Acta Cytol. 1995 Sep-Oct; 39(5):877-81.

10. Feichter GE, Haberthur F, Gobat S, Dalquen P. Breast cytology- statistical analysis and cytohistologic correlations. Acta Cytol. 1997 Mar-Apr; 41(2):327-32.

11. Joshi A, Kapila K, Verma K. Fine needle aspiration cytology in the management of male breast masses. Nineteen years of experience. Acta Cytol. 1999 MayJun;43(3):334-38.

12. Bhat N, Rosato EF, Gupta PK. Gynecomastia in a Mortician. Acta Cytol. 1990 Jan- Feb;34(1):31-34.

13. Amrikachi M, Green LK, Rone R, Ramzy I. Gynecomastia- cytologic features and diagnostic pitfalls in fine needle aspirates. Acta Cytol. 2001 NovDec;45(6):948-52.

14. Rai B, Ghoshal S, Sharma SC. Breast cancer in males: A PGIMER experience. J Can Res Ther. 2005 Jan- Mar;1(1):31-33.

15. Amrikachi M, Green LK, Rone R, Ramzy I. Gynecomastia: Cytologic features and diagnostic pitfalls in fine needle aspirates. Acta Cytol. 2001 NovDec;45(6):948-52.

16. Coghill S, Howat A. Inflammatory conditions and benign breast lesions. In: Diagnostic Cytopathology. Gray W, McKee GT. Elsevier 2004. 2nd edn. Pg 257 78.

\section{How to cite this article?}

Ganguly S, Sheikh SA, Phukan A, Das J, Das S.S. Spectrum of male breast lesions: an institutional perspective. Int $J$ Med Res Rev 2016;4(3):381-386. doi: 10.17511/ijmrr.2016.i03.17
17. Silverman JF, Saad RS. Breast. In: Comprehensive Cytopathology. Bibbo M, Wilbur D. Elsevier 2008. 3rd edn. P. 713-772.

18. Lilleng R, Paksoy N, Vural G, Langmark F, Hagmar B. Assessment of fine needle aspiration cytology and histopathology for diagnosing male breast masses. Acta Cytol 1995 Sep- Oct;39(5):877-881.

19. Martin-Bates E, Krausz T, Phillips I: Evaluation of fine needle aspiration of the male breast for the diagnosis of gynecomastia. Cytopathol. 1990;1 (2):7985 .

20. Russin VL, Lachowicz C, Kline TS. Male breast lesions: gynecomastia and its distinction from carcinoma by aspiration biopsy cytology. Diagn Cytopathol. 1989;5(3):243-47.

21. Heller KS, Rosen PP, Schottenfeld D, Ashikari R, Kinne DW. Male breast cancer: A clinicopathologic study of 97 cases. Ann Surg 1978 Jul;188(1):60-65.

22. Wilson JD, Aiman J, Mac Donald PC. The pathogenesis of gynecomastia. Adv Intern Med 1980;25:1-32.

23. Ersek RA, Schaeferle M, Beckham P. Gynecomastia: Aesthet Surg J 2000 Sep(5):381-86.

24. MacIntosh RF, Merrimen JL, Barnes PJ. Application of the probabilistic approach to reporting breast fine needle aspiration in males. Acta Cytol. 2008 Sep- Oct;52(5):530-34.

25. Westend PJ, Jobse C. Evaluation of fine-needle aspiration cytology of breast masses in males. Cancer. 2002 April 25;96(2):101-04.

26. Wauters CA, Kooistra BW, Heijden IMK, Strobbe LJ. Is cytology useful in the diagnostic workup of male breast lesions? A retrospective study over a 16-year period and review of the recent literature. Acta Cytol. 2010 May- Jun; 54(3):259-64. 